Meta

Journal des traducteurs

Translators' Journal

\title{
Israeli Market Needs for Arabic Translations
}

\section{Abraham Robinson}

Volume 43, numéro 1, mars 1998

La traduction et l'interprétation en Israël

Translation and Interpreting in Israel

URI : https://id.erudit.org/iderudit/003967ar

DOI : https://doi.org/10.7202/003967ar

Aller au sommaire du numéro

Éditeur(s)

Les Presses de l'Université de Montréal

ISSN

0026-0452 (imprimé)

1492-1421 (numérique)

Découvrir la revue

Citer cet article

Robinson, A. (1998). Israeli Market Needs for Arabic Translations. Meta, 43(1), 95-97. https://doi.org/10.7202/003967ar

\section{Résumé de l'article}

L'auteur brosse un tableau des besoins d'Israël en traduction vers l'arabe suivant les divers domaines d'activité socio-économique.
Ce document est protégé par la loi sur le droit d'auteur. L'utilisation des services d’Érudit (y compris la reproduction) est assujettie à sa politique d'utilisation que vous pouvez consulter en ligne.

https://apropos.erudit.org/fr/usagers/politique-dutilisation/ 


\title{
ISRAELI MARKET NEEDS FOR ARABIC TRANSLATIONS 1
}

\author{
ABRAHAM ROBINSON
}

Kadim, Netanya, Israel

\author{
Résumé \\ L'auteur brosse un tableau des besoins d'Israël en traduction vers l'arabe suivant les \\ divers domaines d'activité socio-économique.
}

\begin{abstract}
This article looks at the growing need for Arabic translations in Israel. It comments on the areas of need, safeguards required and the attempts at translator training.
\end{abstract}

In recent years, the Israeli market requirement for Arabic translation has accelerated measurably, the prime reasons being as follows:

- The peace procedure has created the climate for nurturing contacts between Israel and the Arabs, both in the commercial and Governmental sectors.

- The growing awareness by commercial elements who market goods and services in Israel, of the consumer spending power of the Arab sector, and the need to cater for this requirement in the Arabic language. This is despite the fact that most of the Arabs in Israel are acquainted with the Hebrew language.

- An increasingly significant proportion of the material destined for neighbouring Arab countries and originating in the West (Europe and America) is given to Israeli companies for translation into Arabic, and also for the addition of graphical layout. Translation areas:

1. Television and films - Subtitles for most films and translation of broadcasts and reports from all channels. Channel Two is broadcasting programmes in Arabic and screens more and more films with translations into Arabic; Channel Three devotes a large proportion of its broadcasting time to Arabic; the educational television channels are intensifying their programmes in Arabic, but in addition to all of these there is a need for translating films transmitted via media other than on 'the small screen'. Many of these translations are of poor quality and one could be forgiven for presuming that the translator had been unable for some reason to actually view the film judging by the choice of vocabulary in relation to context. Significantly remuneration for operatives in this field is traditionally low.

2. Education - Study programmes in book-form which deal with educational requirements for peace and democracy are translated into Arabic for the needs of the educational system of the Arabs in Israel. A lot of text books are translated into Arabic for the needs of the Israeli markets as well as to Arab Countries. Most of these text books are in English studies and natural sciences. In addition to this, educational games and general pastimes like Scrabble, plus teaching software programmes are adapted into Arabic.

3. Technology - Manuals and booklets on how to use computers, electrical equipment, vehicles and domestic appliances. An element of this work emanates from Western 
Countries destined for Arab Countries, and finds itself 'in transit' in Israel receiving attention to both the translation requirement and sometimes also to graphical layouts.

4. Psychometric Exams and Employment Exams - Whether computerized or otherwise, translators are sometimes required to work from sub-standard material. There are difficulties in making accurate translations due to lack of practice in handling colloquial material. The end-users are based both in Israel and Arab Countries.

5. Signs - Zoos, Museums, Nature reserves, etc.

6. Medicine - Medical leaflets and instructions for medical equipment. The Law in Israel requires translation of every medical leaflet into Arabic as well as English. Some pharmaceutical companies complete this work in-house, whilst others use outside agencies.

7. Safety - Instructions for safety equipment such as helmets for motor bikes and for construction sites. The prevailing statutory requirement to translate to Arabic as well as English is the same as with medical leaflets above.

8. Advertisements - Aimed specifically at the Arab population residing in Israel. The main advertisers are companies selling goods and services, banks, supermarkets, shopping malls which are near to Arab settlements (such as Upper Nazareth), construction companies and credit card companies. In these fields it is necessary to ensure cultural compatibility and not merely translation. Full attention must be paid to pictures and graphics to ensure no offence is given through indecency. Some of the major players in this field have their own Arabic departments. Advertisements aimed at the Arabs in Israel are by way of the press including the Hebrew press, radio, television, bill-boards, brochures and quasi-legal T.V. networks, operating in most of the Arab settlements in Israel.

9. Games - Instructions for games in Arabic: educational, social and computergames. Cultural compatibility must also here be recognised.

10. Official Documentation - Instructive documentation for the transfer of control in Judea, Samaria and Gaza to the Palestinian Authorities in the different areas of administration i.e. instructions for income tax officials for transfer to Arabic computerised data bases (for the needs of the Palestinian authority). Direct approach where necessary such as with the distribution of gas masks, translation of documents emanating from and destined for Arab Countries and documents transmitting information to and from meetings and conferences.

11. Guides - For distribution to Arab Countries (Israeli Industrial Directory) and for the Arab public in Israel such as telephone guides and Yellow Pages.

12. Agriculture - Instructions for agricultural machinery, for irrigation systems, disinfecting materials and fertilizers.

13. Dictionaries - In this field the activities are narrow. There are some computerized dictionaries and others are in preparation. Little activity has taken place in this field of late with the noted exception of the publication by Shlomo Alon. The translators need to use English to Arabic dictionaries. Again, care and sensitivity must be employed in vocabulary selection, paying due deference to local sensitivities. Despite the gap in the market place, few competent operators exist in this field who can achieve the required standards of speed, accuracy and many times cannot produce the end work in disk format. For some years two courses for recruiting translators to Arabic have been conducted, and the participants are Jews and Arabs alike. A third and more intensive course has been established which incorporates nominal use of Apple Macintosh computers. The course is run thanks to Bet Berl College and it is hoped that they will assist in resolving the problems previously covered. About Kadim: the business evolved from a partnership between Abraham Robinson and Julian Millett. Combining the business management and experience of a recognised entrepreneur, previously operating in the U.K. and the Far East, with 
the indigenous talents of a recognised Islamic scholar of enormous experience, Kadim has steadily grown since it's inception in late 1994. Founded on the four basic principles of accuracy, consistency, delivery on time and cost consciousness, Kadim has found a welcoming niche amidst the wealth of opportunity from a marketplace hungry for trustworthy partnerships.

Note

1. Translated by Julian Millett from a Hebrew article published in Targima, Journal of the Israeli Association of Translators (\#35, December 1995 pages 44-45) according to a lecture given at The International Congress "Communication and the Future: The role of communication and translation in technology transfer"; Technion, Haifa, Israel 15-17 May 1995. 